\title{
Psychosis-like absence status of elderly patients: successful treatment with sodium valproate
}

\author{
M IIVANAINEN, L BERGSTRÖM, A NUUTILA, M VIUKARI \\ From the Departments of Neurology and Psychiatry, University of Helsinki and Koskela Geriatric Hospital, \\ Helsinki, Finland
}

SUMMARY Absence status and psychosis-like behaviour and continuous spike-and-wave EEG activity in two elderly women is reported. Once the correct diagnosis was made, the patients were successfully treated with sodium valproate. Differential diagnosis between absence status and psychotic syndromes is emphasised.

The diagnosis of absence or petit mal status (also called "ictal stupor" or "spike-wave stupor") is based on the occurrence of generalised and fairly continuous typical $3 \mathrm{~Hz}$ spike-and-wave activity in the electroencephalogram (EEG) of a patient who is in a confused state for many hours or even days. These spike-and-wave complexes are frequently atypical. ${ }^{1}$

Absence status is a poorly understood and often mis-diagnosed condition. It is most common in children, ${ }^{2}$ and is rare in adults over the age of $50 . .^{3}$ In adults, it is often associated with other forms of epilepsy, including tonic-clonic seizures or myoclonus, ${ }^{4}$ as well as frontal lobe abnormalities such as asymmetry and cortical and central atrophy. ${ }^{5}$ Psychic symptoms of absence status, especially confusion, may be difficult to differentiate from psychosis, but this difference is not well documented.

Treatment of this condition with diazepam or clonazepam is usually not rewarding despite a rather good initial effect. ${ }^{6}$ Sodium valproate, however, has been reported to be useful in the treatment of absence status in a child.' Orally administered sodium valproate has also been effective in the treatment of convulsive status epilepticus in a patient who had failed to respond to other antiepileptic drugs, including diazepam, paraldehyde, and chlormethiazole. ${ }^{8}$

We report here our experience based on two dif-

Address for reprint requests: Dr Matti V livanainen, Department of Neurology, University of Helsinki, Haartmaninkatu 4, SF-00290 Helsinki 29, Finland.

Received 22 December 1983

Accepted 18 February 1984 ferent types of psychosis-like absence status in women over 50 years. Both patients had a positive response to valproate. We emphasise the importance of the early correct diagnosis, based on appropriate differential diagnostic evaluation, including the EEG.

\section{Case reports}

\section{Case 1}

This 57-year-old woman had had generalised tonic-clonic seizures since the age of 7 years, and absence seizures since the age of 32. Her mental development was normal. At the younger age, she had experienced 1 to 5 tonic-clonic seizures per month in spite of an anticonvulsant regimen, later, she had only 4 or 5 per year.

At the age of 55 years, the patient reported having twilight states lasting 2 to 4 hours almost every day. These episodes did not respond to antipsychotic medication (chlorpromazine). Eighteen months later, she had 6 twilight states, the first one lasting 4 days (table). The EEG showed almost continuous $3-\mathrm{Hz}$ spike-and-wave activity, mostly with two spikes in a complex that lasted during the whole recording (fig 1). Sensory input such as opening of the eyes or photic stimulation caused clear diminution of paroxysmal activity. The simultaneous behaviour of the patient was confused and stuporous. She gave only stereotyped and inadequate answers to questions and could later only partially remember the events.

The EEG played a major role in the proper diagnosis and treatment of this disorder because earlier her twilight states had been interpreted as temporal lobe seizures. Sodium valproate, $900 \mathrm{mg}$ daily, was substituted for her previous anticonvulsant regimen of a combination of carbamazepine, phenytoin, phenobarbital, and diazepam. Her twilight state ceased within one day, and later twilight states were shorter.

No cause for her epilepsy could be shown. Physical and neurological examinations, including plain skull radiogra- 
Table Clinical seizures, EEG findings, and antiepileptic drugs in a patient with intractable epilepsy during 16 months in hospital (Case 1).

\begin{tabular}{|c|c|c|c|c|}
\hline Clinical seizures & $E E G$ findings & $\begin{array}{l}\text { Antiepileptic } \\
\text { drugs }\end{array}$ & $\begin{array}{l}\text { Daily dosage } \\
\text { (mg) }\end{array}$ & $\begin{array}{l}\text { Serum drug } \\
\text { level ( } \text { umolll) }\end{array}$ \\
\hline $\begin{array}{l}\text { Absence status for } 4 \text { days, and then } \\
6 \text { twilight states within } 1 \text { month }\end{array}$ & $\begin{array}{l}\text { Continuous } \\
\text { spike-and-wave activity }\end{array}$ & $\begin{array}{l}\text { Carbamazepine } \\
\text { Phenytoin } \\
\text { Phenobarbitone } \\
\text { Diazepam }\end{array}$ & $\begin{array}{r}1,000 \\
200 \\
100 \\
10\end{array}$ & $\begin{array}{r}19 \\
36 \\
108 \\
-\end{array}$ \\
\hline $\begin{array}{l}\text { Twilight states ceased after treatment; } \\
7 \text { tonic-clonic and } 8 \text { absence seizures } \\
\text { within } 2 \text { months }\end{array}$ & $\begin{array}{l}\text { Short } 3 \mathrm{~Hz} \text { paroxysms, } \\
\text { mainly } 3 \mathrm{~Hz} \text { slow-wave } \\
\text { trains without spikes }\end{array}$ & Sodium valproate & 900 & 500 \\
\hline $\begin{array}{l}1 \text { to } 3 \text { tonic-clonic seizures per month } \\
\text { for } 4 \text { months }\end{array}$ & $\begin{array}{l}\text { Short } 3 \mathrm{~Hz} \text { paroxysms, } \\
\text { mainly } 3 \mathrm{~Hz} \text { slow-wave } \\
\text { trains without spikes }\end{array}$ & Sodium valproate & $\begin{array}{l}1,200 \\
1,500\end{array}$ & $\begin{array}{l}366 \\
457\end{array}$ \\
\hline Absence seizures for 4 months & $\begin{array}{c}\text { Short } 3 \mathrm{~Hz} \text { paroxysms, } \\
\text { mainly } 3 \text { Hz slow-wave } \\
\text { trains without spikes }\end{array}$ & $\begin{array}{l}\text { Sodium valproate } \\
\text { Phenobarbitone }\end{array}$ & $\begin{array}{r}1,800 \\
50\end{array}$ & $\begin{array}{l}240 \\
136\end{array}$ \\
\hline No seizures for 5 months & $\begin{array}{c}\text { Short } 3 \mathrm{~Hz} \text { paroxysms, } \\
\text { mainly } 3 \mathrm{~Hz} \text { slow-wave } \\
\text { trains without spikes }\end{array}$ & $\begin{array}{l}\text { Sodium valproate } \\
\text { Phenobarbitone }\end{array}$ & $\begin{array}{r}1,800 \\
100\end{array}$ & $\begin{array}{l}240 \\
-\end{array}$ \\
\hline
\end{tabular}

phy and radioisotope brain scan showed no abnormalities, and the results of complete blood cell counts, urine analysis, Wasserman's complement fixation test, and blood chemistry series were all normal.

Because the patient still had 1 to 3 tonic-clonic seizures and 1 to 3 absence seizures per month, the dosage of valproate was increased. Two months later (that is 20 months after her first twilight states), the serum valproate level was $500 \mu \mathrm{mol} / \mathrm{l}$. The EEG showed short $3 \mathrm{~Hz}$ paroxysms consisting mainly of slow-wave trains (fig 2). The daily dosage of valproate was increased to $1200 \mathrm{mg} 2$ months later and to $1500 \mathrm{mg}$ another month later. Thereafter, phenobarbitone, up to $100 \mathrm{mg}$ was added to the regimen at night to control nocturnal tonic-clonic seizures. Five months later, the serum valproate level was $230 \mu \mathrm{mol} / \mathrm{l}$, and the serum phenobarbitone level was $136 \mu \mathrm{mol} / \mathrm{l}$. No tonic-clonic seizures were noted, but the patient still had absences. During these episodes, she was noncommunicative and had a staring expression. The daily dosage of sodium valproate was increased to $1800 \mathrm{mg}$ (900 mg twice a day), and thereafter no seizures were noted during the follow-up period of 5 months.

\section{Case 2}

This 63-year-old woman had had normal development and good health before her first epileptic attack, which was an absence seizure at the age of 57 years. During the following 4 years she had had some other absence seizures before her first tonic-clonic seizure at the age of 61 years. After that tonic-clonic seizure she had had a postictal confusion state. Six weeks later she was admitted to hospital, because of frequent absences. In the hospital she had an absence status lasting the whole day.

Detailed clinical examination, including computed tomography (CT) of the head and the other examinations listed in our Case 1, did not show any cause for her epilepsy. The EEG recorded during the absence status showed $3 \mathrm{~Hz}$ spike-and-wave activity lasting the whole recording. The paroxysmal activity was, however, interrupted sharply at irregular intervals by a low-voltage activity lasting 1 to 7 seconds. Opening of the eyes or photic stimulation did not cause any diminution of paroxysmal activity.
Sodium valproate, $900 \mathrm{mg}$ daily, was substituted for her previous antiepileptic regimen of phenytoin (300 mg daily). Her absence seizures ceased completely during the valproate monotherapy. The EEG showed significant improvement of the $3 \mathrm{~Hz}$ paroxysms and consisted mainly of slow-wave trains. The daily dose of sodium valproate was reduced to $750 \mathrm{mg}$ after 3 years treatment. The good result has now continued 4 years.

\section{Discussion}

The absence status in these elderly patients responded to sodium valproate, but control of the tonic-clonic seizures of Case 1 was achieved only by a combination of valproate and phenobarbitone. The seizures of Case 2 were well controlled with valproate monotherapy. At the time of the absence status, the EEG included spike-and-wave complexes in both cases, but during valproate treatment, the EEG paroxysms consisted mainly of $3 \mathrm{~Hz}$ slow-wave trains without spikes and very few typical spikeand-wave patterns. Thus, the EEG was a decisive aid for confirming the diagnosis of absence status. It should be noted, however, that the EEG may show spike-and-wave status epilepticus in persons with normal behaviour, ${ }^{8}$ a fact that stresses the significance of careful clinical observation.

Prolonged temporal absences and interictal epileptic and other psychoses are clinically difficult to differentiate from absence seizures. ${ }^{19}$ The former was the most essential differential diagnostic problem in our patients, as the therapy is different in temporal absences from that in absence seizures. In the former, carbamazepine is the drug of choice whereas in the latter valproate or ethosuximide is preferred. Thus, the EEG findings are essential for the correct diagnosis and treatment of absence status.

Differential diagnosis between complex partial or 


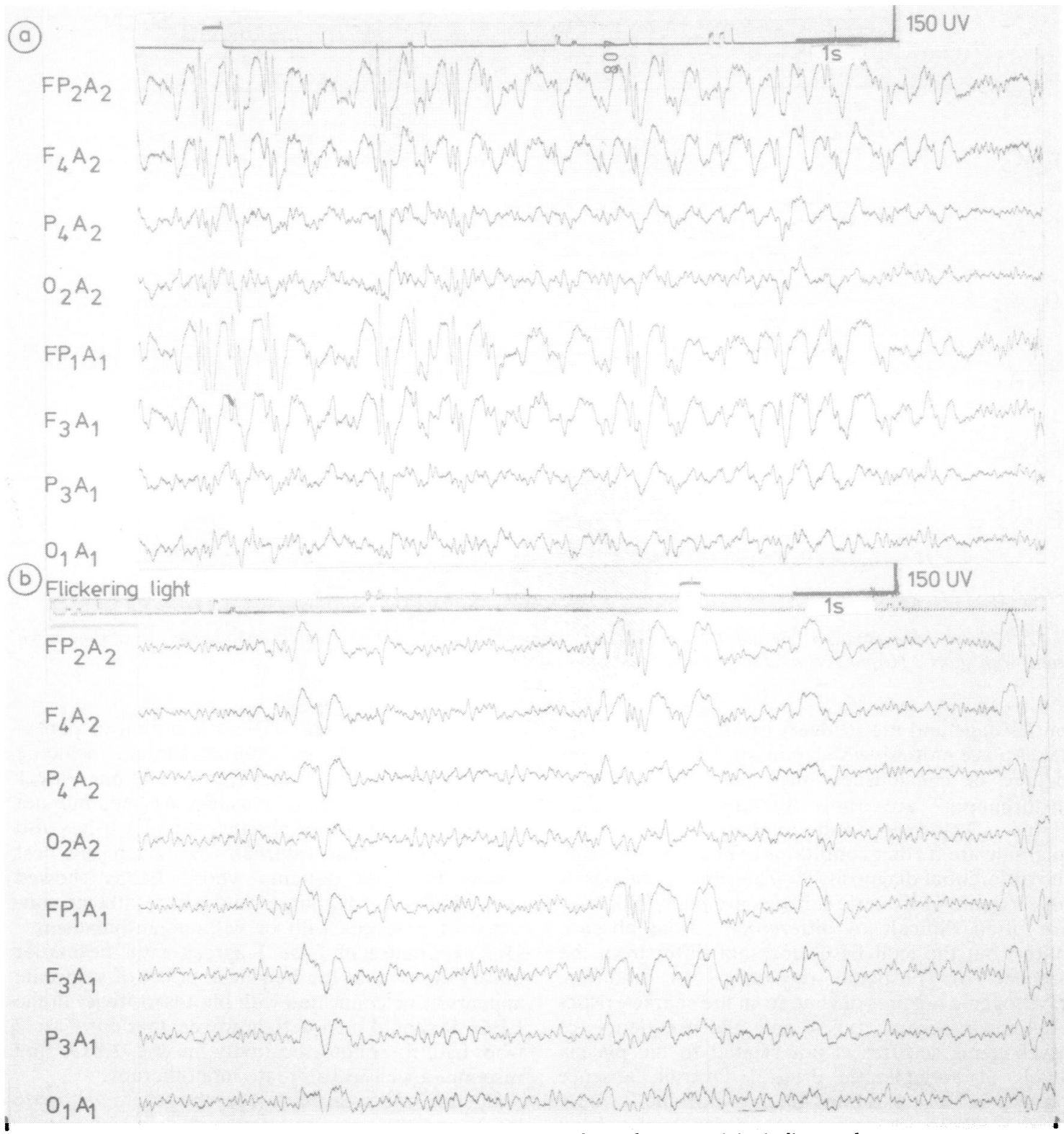

Fig 1 (a) Electroencephalogram before valproate treatment: spike-and-wave activity indicates absence status. (b) Paroxysmal activity is inhibited by flickering light (Case 1).

temporal seizures and absence seizures is based on several clinical features including the presence of aura (occasional in complex partial seizures, not in absence seizures), that of postictal confusion (not in absence seizures), type of automatism (trunk and leg in complex partial seizures, but face and hands in absence seizures), frequency of clonic components $(15 \%$ in complex partial seizures and $45 \%$ in absence seizures), duration of single seizures (on an average one minute in complex partial seizures and 10 seconds in absence seizures). The duration of complex partial seizures may last up to 2 minutes when confusion is included. ${ }^{10}$

Other disorders which need to be remembered in the differential diagnosis of absence status are organic confusion states other than epilepsy. The 


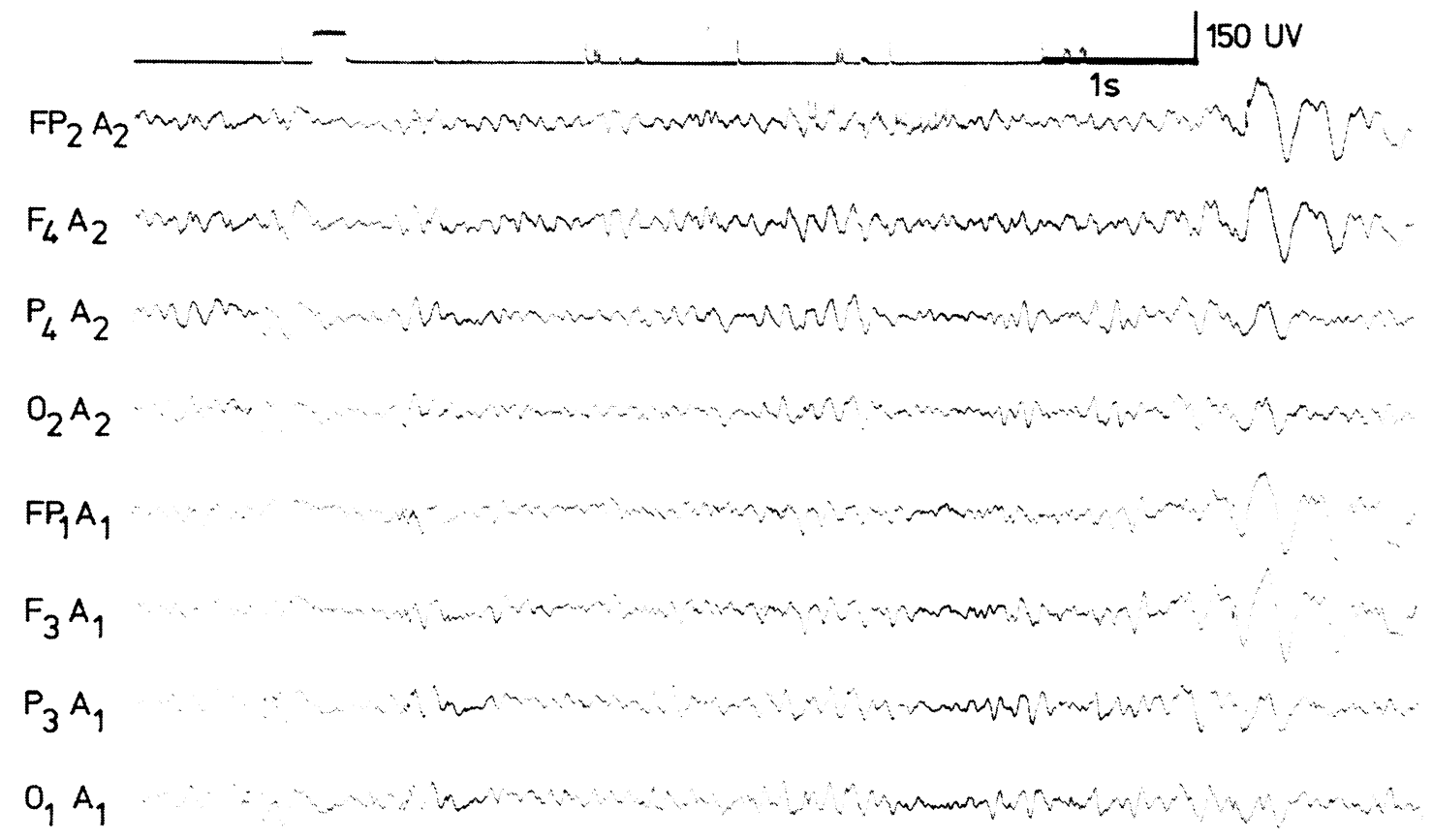

Fig 2 Electroencephalogram 2 months later, during treatment with sodium valproate: activity mainly consists of slow-wave trains with short $3 \mathrm{~Hz}$ paroxysms showing significant improvement (Case 1).

initial stage and the recovery of many such patients takes place more slowly step by step. In addition, the degree of conciousness may be reduced. These disturbances are not features of absence status. Transient and global amnesia and migraine are further conditions to be kept in mind in the differential diagnosis. ${ }^{112}$ The clinical findings of psychogenic or hysteric seizures are manyfold; they are often difficult to differentiate from absence status, but the ictal EEG does not differ from the preictal or postictal recording. In addition, psychogenic seizures deviate from the characteristics of known seizure types and the frequency of psychogenic seizures is not related to the plasma levels of antiepileptic drugs. ${ }^{13}$ Overall, absence status is a psychosis-like syndrome where psychopathological symptoms and signs such as axial amnesia and desorientation are typical, but, for example, speech functions are usually rather well preserved and there are no hallucinations. Afterwards these patients have amnesia for their absence status.

The effect of valproate on the EEG has not been studied systematically, but valproate may initially induce slowing of the EEG background activity and later accentuate beta frequencies. ${ }^{14}$ Clinical improvement may precede or parallel the reduction in paroxysmal activity. ${ }^{15}$ The diminution of paroxysmal EEG activity by external stimuli, including eye opening or photic stimulation, as in our Case 1 (but not in Case 2), is a well-described, but not necessary indication of absence status. ${ }^{16}$ It has also been reported that valproate has given the best results in those patients whose EEGs showed spike-and-wave discharges and whose attacks consisted of absences with or without automatisms. ${ }^{17}$ Our experience of Case 1 agrees with the earlier observations ${ }^{7}$ that the beneficial effect of valproate appears to be connected with photosensitivity in the EEG. It should be noted, however, that our Case 2 who had no photo-sensitivity in the EEG, and responded well to valproate monotherapy.

In spite of increased dosage, the serum valproate levels and the anticonvulsant effect in our Case 1 tended to decline during the long-term administration of valproate in combination with phenobarbitone. Obviously, these findings were related to the development of tolerance to the antiepileptic effect of valproate, which may be partially due to hepatic microsomal enzyme induction. ${ }^{18}$

Absence status is a rarity in elderly persons. Differential diagnosis with careful clinical documentation and EEG assessment cannot be overemphasised. Furthermore, absence status is a treatable dis- 
order. For these reasons, the present experience of absence status in patients over 50 years may be worth considering. The patients obtained relief with valproate, which appears to be a promising drug for absence with or without photosensitivity.

This work was supported in part by Orion Research Foundation. The valuable suggestions of $\mathrm{Dr} \mathrm{C}$ Ajmone Marsan are greatly appreciated.

\section{References}

' Niedermeyer E, Khalifeh R. Petit mal status ("spikeand-wave stupor'). An electro-clinical appraisal Epilepsia 1965;6:250-62.

${ }^{2}$ Shev EE. Syndrome of status petit mal in the adult. Electro-encephalogr Clin Neurophysiol 1964;17:466.

${ }^{3}$ Lob H, Roger J, Soulayrol R, Regis H, Gastaut H. Les états de mal généralises à r'éxpression confusionelle (états de petit mal ou etats d'absence). In: Gastaut $\mathrm{H}$, Roger $\mathrm{J}$, Lob $\mathrm{H}$, eds. Les états de mal épileptiques. Paris: Masson and Cie 1967:91-109.

${ }^{4}$ Terzano MG, Gemignam F, Mancia D. Petit mal status with myoclonus: Case report. Epilepsia 1978; 19:385-92.

${ }^{5}$ Gall M, Scollo-Lavizzari G, Becker H. Absence status in the adult. New results including computerised transverse axial tomography. Eur Neurol 1978;17:121-8.

${ }^{6}$ Lagenstein I, Iffland E. Die intravenöse Behandlung des Petit-Mal-Status mit Diazepam und Clonazepam. Electroencephalogr Electromyogr 1977;8:82-8.

' Sillanpää M, Donner M. Experiences on the use of dipropyl-acetate in the treatment of childhood epilepsy. Acta Pediatr Scand 1976;65:209-15.
${ }^{8}$ Manhire AR, Espir M. Treatment of status epilepticus with sodium valproate. $\mathrm{Br}$ Med $J$ 1974;3:808.

${ }^{9}$ Fincham RW, Yamada T, Schottelius DD, Hayreh SMS, Damasio A. Electroencephalographic absence status with minimal behaviour change. Arch Neurol 1979; 36:176-8.

${ }^{10}$ Theodore WH, Porter RJ, Penry JK. Complex partial seizures: Clinical characteristics and differential diagnosis. Neurology (Cleveland) 1983;33:1115-21.

" Damasio AR, Graff-Radford NR, Damasio H. Transient partial amnesia. Arch Neurol 1983;40:656-7.

12 Caplan L, Chedru F, Lhermitte F, Mayman C. Transient global amnesia and migraine. Neurology (NY) 1981;31:1167-70.

${ }^{13}$ Desai BT, Porter RJ, Penry JK. Psychogenic seizures. A study of 42 attacks in six patients, with intensive monitoring. Arch Neurol 1982;39:202-9.

${ }^{14}$ Sackellares JC, Sato S, Dreifuss FE, Penry JK. The effect of vaproic acid on the EEG background. In: Wada JA, Penry JK, eds. Advances in Epileptology: The Xth Epilepsy International Symposium. New York: Raven Press 1980:132.

${ }^{15}$ Simon D, Penry JK. Sodium di-N-propylacetate (DPA) in the treatment of epilepsy: A review. Epilepsia 1975; 16:549-75.

${ }^{16}$ Landolt H. Über die Symptomatologie der epileptischen Absenz mit Spike-and-Wave-Komplexen im EEG. Schweiz Arch Neurol Psychiatr 1976;78:377-80.

17 Jeavons PM, Clark JE. Sodium valproate in treatment of epilepsy. Br Med J 1974;2:584-6.

${ }^{18}$ Oxley J, Richens A. The liver enzyme including properties of sodium valproate. In: Wada JA, Penry JK, eds. Advances in Epileptology: The Xth Epilepsy International Symposium. New York: Raven Press 1980:358. 